\title{
INTRODUCTION TO THEORETICAL PSYCHOLOGY
}




\section{INTRODUCTION TO THEORETICAL PSYCHOLOGY}

\section{MICHAEL HYLAND}

Department of Psychology,

Plymouth Polytechnic 
(C) Michael Hyland 1981

Softcover reprint of the hardcover 1st edition 1981

All rights reserved. No part of this publication may be reproduced or transmitted, in any form or by any means, without permission

First published 1981 by

THE MACMILLAN PRESS LTD

London and Basingstoke

Associated companies in Delhi Dublin.

Hong Kong Johannesburg Lagos Melbourne

New York Singapore and Tokyo

British Library Cataloguing in Publication Data

Hyland, Michael

Introduction to theoretical psychology

1. Psycnology

I Title

$150^{\prime} .1$

BF121

ISBN 978-0-333-25827-9 ISBN 978-1-349-16464-6 (eBook)

DOI 10.1007/978-1-349-16464-6

This book is sold subject to the standard conditions of the Net Book Agreement

The paperback edition of this book is sold subject to the condition that it shall not, by way of trade or otherwise, be lent, resold, hired out, or otherwise circulated without the publisher's prior consent in any form of binding or cover other than that in which it is published and without a similar condition including this condition being imposed on the subsequent purchaser 


\section{Contents}

Preface

viii

1 Why use Theories? 1

Behaviourism versus Theoretical Psychology 2

Data, Theories and the History of Science 11

2 Introduction to theories: Predictive Power, Form,

Content

$\begin{array}{ll}\text { Predictive Power } & 16\end{array}$

Describing a Theory 18

Form $\quad 19$

Content 24

$\begin{array}{ll}\text { Processes } & 28\end{array}$

3 Hypothetical Constructs and Intervening Variables 32

Construct Validity $\quad 37$

Explanatory Fictions 39

Using Hypothetical Constructs and Intervening Variables

4 The Nature of Hypothetical Constructs 42

The Operational Component 43

The Nature Component $\quad 45$

Physiological Hypothetical Constructs $\quad 46$

Mentalistic Hypothetical Constructs $\quad 48$

Mechanistic Hypothetical Constructs $\quad 50$

Identity Relations $\quad 54$

5 Causal Relations in Psychology 59

$\begin{array}{ll}\text { What is a Cause? } & 60\end{array}$

Relations between Hypothetical Constructs 62 
Relations between Hypothetical Constructs and the Situation

Relations between Hypothetical Constructs and Behaviour 69 Physiological Psychology and Psychophysiology 70 Mentalistic Hypothetical Constructs, Reasons and Causes 71 Causal Processes and Pseudoprocesses

6 Operators

Simple and Complex Operators

Consequences of using Simple and Complex Operators $\quad 80$

Differences in the Form of an Operator

Identity Relations between Operators and Hypothetical Constructs

7 Theories

8 Explaining What?

Explanatory Concepts which refer to Hypothetical

Constructs

Energy Concepts

Directional Concepts

104

Performance Concepts

Use of and Relation between Energy, Directional and Performance Concepts

Explanatory Concepts which refer to Differences, Changes or Relations amongst Hypothetical Constructs

Individual Differences, Situational Differences and Interactionism

Learning Concepts

Perception Concepts

Combinations of Explanatory Concepts: Perceptual

Learning and Motivated Perception

Conclusion: Explanatory Concepts

Situations in which the Behaviour to be Explained Occurs 120

9 Testing Theories

From Theories to Data

Experimental and Non-experimental Paradigms 
Difficulties in Extrapolating from Data

References

Further Reading 


\section{Preface}

This is the first textbook to be written solely on theory construction and theory testing in psychology - which is what I term theoretical psychology. In writing it my aim has been predominantly pragmatic: I want psychologists to become more aware of how they should construct better theories, better theories which will then give rise to better and more useful predictions about behaviour. If this book does not lead in the long term to better and more useful predictions then its chief purpose will not have been achieved. There are, however, other advantages to a proper understanding of theoretical psychology. One of them is that it makes it possible to integrate the different areas of psychology. It reveals the theoretical relationship between different sorts of explanation in psychology and shows how empirical research stemming from different areas can be integrated.

There are two things this book is not. First, it is not a definitive textbook of theoretical psychology, because theoretical psychology is such an underdeveloped area. It is more of a starting point for further development, and as such it discusses the existing work on the subject as well as including a good deal which is original. Second, it is not a textbook on the philosophy of psychology. It is not written for those who seek a philosophical understanding of mind, matter, man or psychology, nor does it provide such. The only philosophy in the book is philosophy of science, and that is introduced simply to gain a more general perspective of psychological theories.

I have tried to make the book as simple and straightforward as possible. The intention was to make the book comprehensible to final year and postgraduate psychology students taking one of the many courses which have names such as History and Systems in Psychology, Explanation in Psychology and so forth. I hope that this has been achieved. At the same time the book ought to prove useful to all those conducting psychological research and who are seeking a better appreciation of the theoretical basis of their work. 